\author{
Vladimir S. Poluzanski \\ University of Belgrade \\ School of Electrical Engineering \\ Institute of Nikola Tesla \\ Uros D. Kovacevic \\ Teaching Assistant \\ University of Belgrade \\ Faculty of Mechanical Engineering \\ Bosko D. Nikolic \\ Professor \\ University of Belgrade \\ School of Electrical Engineering
}

\section{Algorithm for Calculating Influence of Power Transformer Oil Temperature Change on the Accuracy of All- Acoustic Non-Iterative Partial Discharge Localization}

This article investigates the all-acoustic method for partial discharge localization in a power transformer. This method is based on mathematical model that uses multilateration with Time Difference of Arrival (TDOA) principle and non-itterative mathematical algorithm. In this model, it is assumed that acoustic signal propagates only through transformer oil and that the velocity of acoustic signal is constant. Acoustic signal velocity is largely dependent on transformer oil temperature meaning that oil temperature is also considered to be constant. In reality if we look from the perspective of physics, thermo dynamics of fluids, transformer construction etc. this approximation is enormous. Therefore, influence of power transformer oil temperature change (velocity of acoustic signal change) on the accuracy of this method is investigated. For that purpose special algorithm is designed and implemented in Visual C\# programming language. Based on conducted simulations, further knowledge is gained about interaction between transformer oil temperature and placement of acoustic sensors. This interaction produced significant disparity in noniterative algorithm's accuracy for different sensor positions with oil temperature change. In order to fully take advantage of noticed interaction, certain steps for further research and development are proposed.

Keywords: power transformer, partial discharge, oil temperature, acoustic measurement, elementary sensitivity, input variables interaction, sensor placement, software.

\section{INTRODUCTION}

A power transformer is individually the most expensive element in the substation whose price is greater than half of the total investment of the new facility. Other costs (installation, maintenance) related to the lifetime of the power transformer are small compared to the price of the new unit. If there is a sudden failure, the costs that may arise can be significantly higher than the cost of the new power transformer and have a global impact on power distribution system.

Failures of the machines are caused by the design errors, fatigue, errors in the manufacturing technology, improper maintenance or the operational conditions which differ from the design assumptions [1]. Long-life operation and maintenance of technical objects requires special attention on the condition monitoring methods, strategies chosen in maintenance routine and evaluation of risks that should be performed to prioritize actions that reduce the global impact on the organization or

Received: November 2017, Accepted: January 2018

Correspondence to: Vladimir Poluzanski

Faculty of Electrical Engineering,

Bulevar Kralja Aleksandra 73, 11120 Belgrade, Serbia

E-mail: vladimir.poluzanski@ieent.org

doi:10.5937/fmet1802183P

(C) Faculty of Mechanical Engineering, Belgrade. All rights reserved system outcomes [1,2].

Complementary employment of different diagnostic methods can determine the trend of insulation system degradation and the dynamics of preventive measures application in power transformers [3]. Partial discharge (PD) is considered to be the principal cause of degradation of the power transformer insulation system. PD occurs when the electric field strength exceeds the dielectric breakdown strength of the insulation medium in localized area [4-6]. PD causes a number of side effects in power transformer insulation system: dielectric losses, gas pressure changes, chemical changes in the composition of materials, acoustic effects, optical effects, thermal effects, electromagnetic radiation and electrical circuit impulse response, electricity and voltage occurrence [7-12]. Prevention and location of partial discharges in a power transformer are essential for their reliable and durable operation. Because of the large capital value of power transformers and their critical role in the electricity network, there is an increasing need for development of non-intrusive diagnostic methods for partial discharge detection. These methods are designed to detect side effects of partial discharge and calculate its location using different mathematical algorithms. Some examples of these methods are: 
- method that detects chemical effects of PD using dissolved gas analysis (DGA) (not able to provide valuable information on location of PD) [13],

- method that detects electricity occurrence caused by PD [14], [15],

- method that detects electromagnetic radiation of PD using ultra high frequency (UHF) sensors [16], [17] or radio frequency (RF) sensors [18],

- method that detects acoustic effects of PD using piezoelectric sensors [19-24],

- method that detects optical effects of PD using fiber-optic sensors [25],

- combined methods, like UHF-acoustic method [26-28].

All of these methods produce mixed results in terms of PD detection accuracy, ease of use, cost effectiveness, application possibilities, noise reduction etc. Accordingly, there is an ongoing need to improve existing methods for PD detection or develop new ones.

The purpose of this article is to improve understanding of the relationship between input and output parameters of mathematical model used by noniterative all-acoustic method. For example, influence of power transformer oil temperature change (velocity of acoustic signal change) on the accuracy of all acoustic method is investigated. For that purpose special algorithm is designed and implemented in Visual C\# programming language. Based on conducted simulations, interaction between power transformer oil temperature and placement of acoustic sensors is observed. This interaction produced significant disparity in non-iterative algorithm's accuracy for different sensors' positions with oil temperature change. This disparity may lead to proposals for optimal sensor positioning which would improve accuracy of PD localization.

Algorithm presented in this paper represents the basis of the greater goal, that is the development of assistant software tool for PD localization by noniterative all acoustic method.

The paper has six chapters. In chapter 2, all-acoustic non-iterative method is explained in detail. Chapter 3 discusses mathematical modelling of physics phenomena, importance of sound velocity for PD localization accuracy, dependence of sound velocity on transformer oil temperature, a procedure to calculate elementary sensitivities. At the end of this chapter an algorithm for calculating influence of the transformer oil temperature change on the accuracy of PD localization is presented. Chapter 4 presents simulations' results. In chapter 5, further research and development is proposed.

\section{ALL-ACOUSTIC NON-ITERATIVE PD LOCATION METHOD}

Acoustic method provides PD detection, localization and PD type identification. Acoustic emission (AE) measurements are commonly performed with piezoelectric ultrasound sensors mounted on the transformer's tank wall. This method is easy to use and does not require expensive equipment. It is noninvasive, elec- tromagnetic interference resistant, thus more suitable for online monitoring application on power transformer. Disadvantages of this method are lower sensitivity, weather condition impact (rain, wind), non-PD vibration sources (loose parts, cooling fans) that interfere with acoustic signal, as well as acoustic signal attenuation during propagation through different materials (cooper, steel, transformer oil, water etc.) [29]. This makes acoustic method suitable for use in combination with other methods but it can also be used like a standalone method.

Mathematical model used for PD localization by allacoustic method is a well known model based on multilateration from GPS localization techniques. One thing that is interesting about this mathematical model is that sound velocity during signal flight from PD to acoustic sensors is considered to be constant. Acoustic signal velocity is largely dependent on transformer oil temperature $[30,31]$, meaning that oil temperature is also considered to be constant. From the perspective of physics, thermo dynamics of fluids, transformer construction etc. this approximation is enormous [31-33]. Nevertheless, reported experimental results for this method are considered to be acceptable for practical use [22].

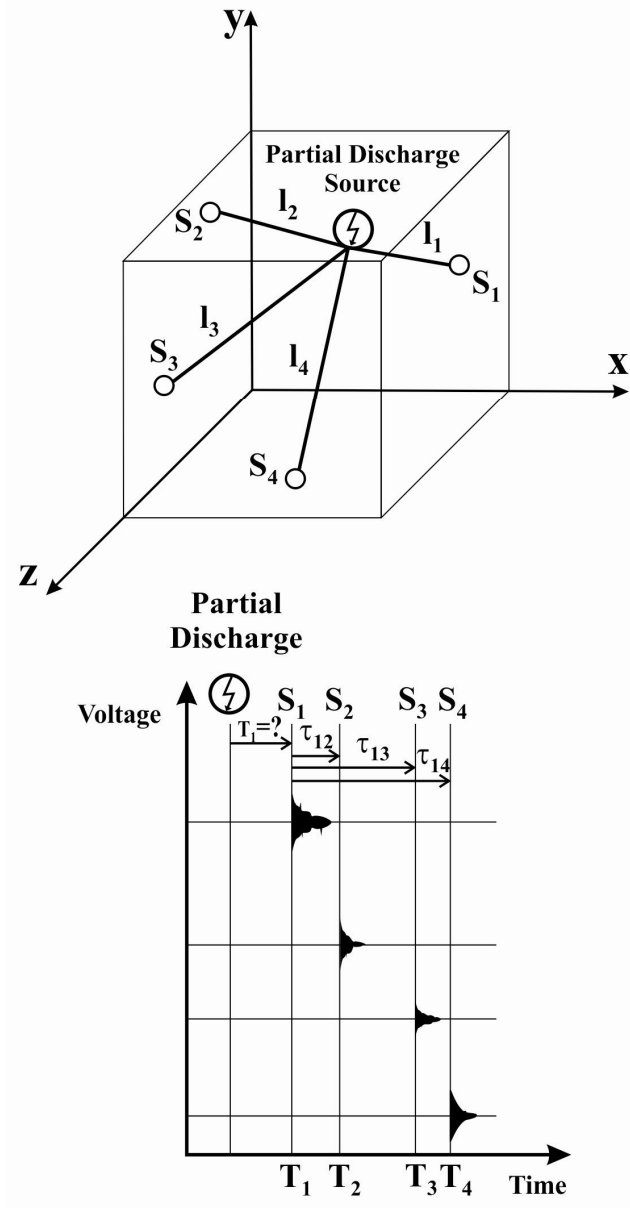

Figure 1. Illustration of the system for detecting the location of partial discharge by non-iterative all-acoustic method

The non-iterative all-acoustic method is based on TDOA principle described by the system of 4 non-linear equations. Solving this system gives PD location. Transformer is observed in the Cartesyan space (Fig. 1). Each sensor has coordinates $x_{S i}, y_{S i}, z_{S i}(i=1, . .4)$, while 
the location of the partial discharge source is marked by coordinates $x, y, z$. The velocity of acoustic signal propagation $v_{s}$ is considered to be constant, while the problem of acoustic signal propagation through materials other than transformer oil is disregarded. Figure 1 shows the appearance of acoustic signals of partial discharge recorded by four acoustic sensors $S_{1}, S_{2}, S_{3}$, $S_{4}$. It illustrates the acoustic signal time delays $\tau_{12}, \tau_{13}$, $\tau_{14}$ between sensors $S_{1}$ and $S_{2}, S_{1}$ and $S_{3}$, as well as $S_{1}$ and $S_{4}$ where $T_{1}<T_{2}<T_{3}<T_{4}$. The time from discharge occurrence to sensor's $S_{l}$ response, $T_{l}$, is unknown. Distances between PD source and sensors $l_{i}, i=1 . .4$, refer to $l_{1}<l_{2}<l_{3}<l_{4}$.

Since the non-iterative mathematical algorithm relies solely on acoustic measurements, it is not necessary to conduct additional electrical or other measurements of partial discharge activities. This algorithm does not have a solution convergence problem. In the field, this method can be applied to transformers in the operating mode, by using only four acoustic sensors mounted on the transformer wall. Since one measurement is sufficient for successful partial discharge detection, the partial discharge source does not need to be active over a lengthy period of time.

\section{ALGORITHM FOR CALCULATING INFLUENCE OF POWER TRANSFORMER OIL TEMPERATURE CHANGE ON PD LOCALIZATION ACCURACY}

\subsection{Mathematical Modelling of Physics Phenomena}

Mathematical modelling is widely used for attacking problems in physics, chemistry, engineering etc. The particular details of each of the problem will, of course, vary widely, but there is a valuable general perspective common to all these areas of modelling. This common touch point is illustrated in Fig. 2 which represents an overall block diagrammatic representation of how modelling is performed [34].

The first step is a mathematical definition of the model, which involves a parametric representation of input information. The next step is to define mathematical equation(s), which will lead to solution e.g. connect the input to the output (scrambler). The solution of these equations leads directly to the set of system observables. With gathered information, we can calculate elementary sensitivities which will ultimately lead to systematic and powerful sensitivity calculus capable of probing fine details as well as overall gross features of a problem [34].

The goal of sensitivity analysis is to probe the relationship between the output and input variables of the system. From a greater perspective all of the variables, both input parameters and output observables, can be considered as a whole, and interrelationships between them probed [35]. Sensitivity analysis can be performed either comprehensively or just partially, by considering selected parameters only.

In the simplest case, which is sufficient for this analysis, sensitivities are equivalent to the first order partial derivatives of the system's response with respect to the system parameters, calculated at the parameters' nominal values.

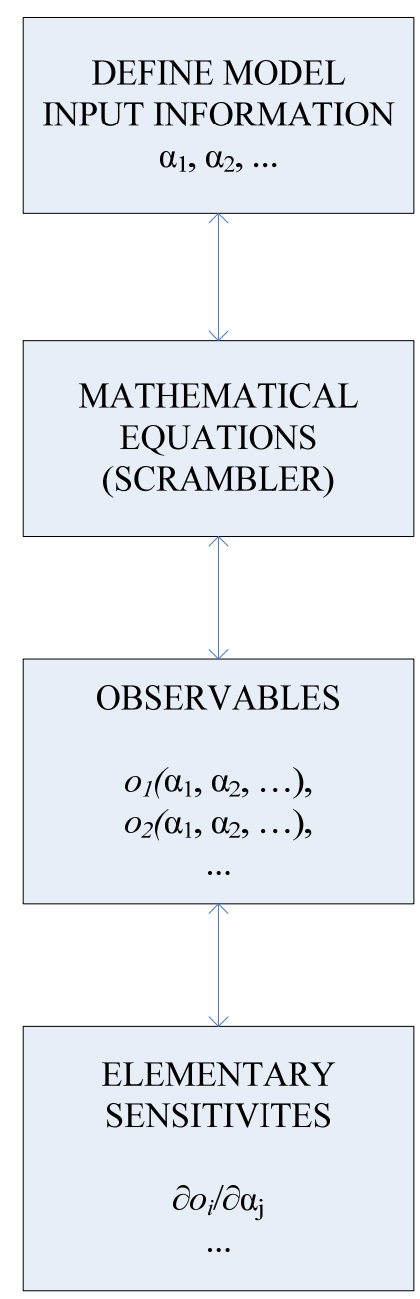

Figure 2. Mathematical modelling of physics phenomena.

Described steps of mathematical modelling represent foundation for construction and implementation of our algorithm. In following chapters each element of mathematical model for the case of non-iterative allacoustic method is described in detail.

\subsection{Model's Input and Output Information}

As described in Chapter 2, the location of partial discharge is detected indirectly. Input and output variables of non-iterative algorithm are:

- velocity of acoustic signal $v_{s}$,

- $\quad$ sensor coordinates: $x_{S i}, y_{S i}, z_{S i}(i=1, . .4)$,

- time differences of arrival: $\tau_{12}, \tau_{13}, \tau_{14}$,

- partial discharge source coordinates: $x, y, z$.

There are 16 input and 3 output variables in this case (Fig. 4).

Apart from these variables, that are directly connected to non-iterative algorithm, other information such as:

- shape and dimensions of considered power transformer,

- $\quad$ range of possible values for $v_{s}$

- range of possible values for transformer oil temperature,

- transformer sides that are used (available) for sensor placement,

also represent valuable model input information. 


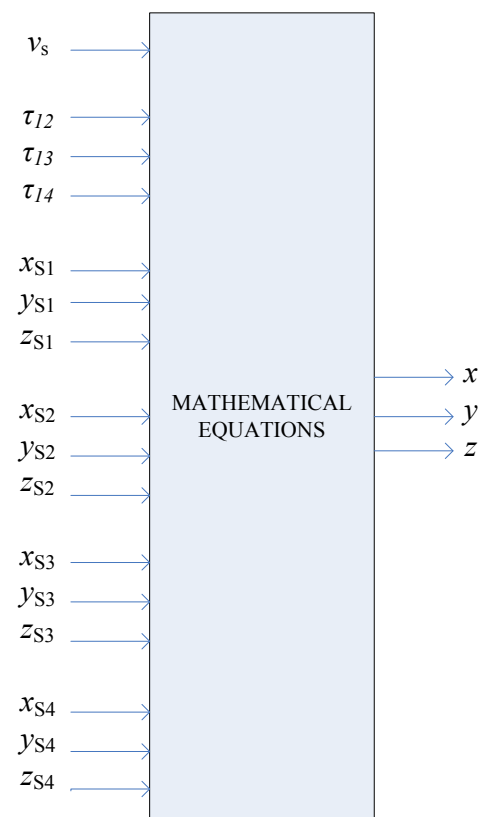

Figure 4. Input and output variables of non-iterative algorithm

\subsection{Mathematical Equations (Scrambler)}

The non-iterative all-acoustic method is based on the TDOA principle described by the system of non-linear equations (1)-(4):

$$
\begin{aligned}
& \left(x-x_{s_{1}}\right)^{2}+\left(y-y_{s_{1}}\right)^{2}+\left(z-z_{s_{1}}\right)^{2}=\left(v_{s} T_{1}\right)^{2} . \\
& \left(x-x_{s_{2}}\right)^{2}+\left(y-y_{s_{2}}\right)^{2}+\left(z-z_{s_{2}}\right)^{2}= \\
& =\left(v_{s}\left(T_{1}+\tau_{12}\right)\right)^{2} . \\
& \left(x-x_{s_{3}}\right)^{2}+\left(y-y_{s_{3}}\right)^{2}+\left(z-z_{s_{3}}\right)^{2}= \\
& =\left(v_{s}\left(T_{1}+\tau_{13}\right)\right)^{2} . \\
& \left(x-x_{s_{4}}\right)^{2}+\left(y-y_{s_{4}}\right)^{2}+\left(z-z_{s_{4}}\right)^{2}= \\
& =\left(v_{s}\left(T_{1}+\tau_{14}\right)\right)^{2} .
\end{aligned}
$$

In order to determine accurate partial discharge coordinates $x, y, z$, it is necessary to solve the system of non-linear equations (1)-(4). In this particular case that is accomplished by non-iterative mathematical algorithm. Bancroft (1985) first provided a mathematical foundation for solving the system of non-linear equations (1)-(4) [34]. Solution from [22] that is implemented in the algorithm is presented here.

Equations (1)-(4) represent a sphere, with the centre at respective sensor position, passing through the source.

Any two of the spheres (1)-(4) intersect and source is located on the intersecting plane. The equation of the intersecting plane for the spheres (1) and (2) can be obtained by taking difference of (1) and (2). This equation of intersecting plane is given in (5). In the following equations, $k_{i}$ are constants.

$$
\begin{aligned}
& 2 x\left(x_{s_{2}}-x_{s_{1}}\right)+2 y\left(y_{s_{2}}-y_{s_{1}}\right)+2 z\left(z_{s_{2}}-z_{s_{1}}\right)+ \\
& +2 v_{s}{ }^{2} \tau_{12} T_{1}=k_{1} .
\end{aligned}
$$

where

$$
\begin{aligned}
& k_{1}=\left(x_{s_{2}}{ }^{2}-x_{s_{1}}{ }^{2}\right)+\left(y_{s_{2}}{ }^{2}-y_{s_{1}}{ }^{2}\right)+ \\
& +\left(z_{z_{2}}{ }^{2}-z_{z_{1}}{ }^{2}\right)-v_{s}{ }^{2} \tau_{12}{ }^{2} .
\end{aligned}
$$

Similarly, the equations for the intersecting planes for spheres (1) and (3) and for spheres (1) and (4) are obtained by taking difference of (1), (3) and (1), (4), respectively. These equations are given in (6) and (7), respectively.

$$
\begin{aligned}
& 2 x\left(x_{s_{3}}-x_{s_{1}}\right)+2 y\left(y_{s_{3}}-y_{s_{1}}\right)+2 z\left(z_{s_{3}}-z_{s_{1}}\right)+ \\
& +2 v_{s}{ }^{2} \tau_{13} T_{1}=k_{2} . \\
& k_{2}=\left(x_{s_{3}}{ }^{2}-x_{s_{1}}{ }^{2}\right)+\left(y_{s_{3}}{ }^{2}-y_{s_{1}}{ }^{2}\right)+ \\
& +\left(z_{z_{3}}{ }^{2}-z_{z_{1}}{ }^{2}\right)-v_{s}{ }^{2} \tau_{13}{ }^{2} . \\
& 2 x\left(x_{s_{4}}-x_{s_{1}}\right)+2 y\left(y_{s_{4}}-y_{s_{1}}\right)+ \\
& +2 z\left(z_{s_{4}}-z_{s_{1}}\right)+2 v_{s}{ }^{2} \tau_{14} T_{1}=k_{3} . \\
& k_{3}=\left(x_{s_{4}}{ }^{2}-x_{s_{1}}{ }^{2}\right)+\left(y_{s_{4}}{ }^{2}-y_{s_{1}}{ }^{2}\right)+ \\
& +\left(z_{s_{4}}{ }^{2}-z_{s_{1}}{ }^{2}\right)-v_{s}{ }^{2} \tau_{14}{ }^{2} .
\end{aligned}
$$

Equations (5)-(7) have the unknown variable $T_{1}$. By eliminating $T_{1}$ from the three equations, two equations of plane are obtained and given in (8) and (9).

$$
\begin{aligned}
& 2 x k_{4}+2 y k_{5}+2 z k_{6}=k_{7} \text {. } \\
& k_{4}=\frac{\left(x_{s_{2}}-x_{s_{1}}\right)}{2 v_{s}{ }^{2} \tau_{12}}-\frac{\left(x_{s_{3}}-x_{s_{1}}\right)}{2 v_{s}{ }^{2} \tau_{13}} \text {. } \\
& k_{5}=\frac{\left(y_{s_{2}}-y_{s_{1}}\right)}{2 v_{s}{ }^{2} \tau_{12}}-\frac{\left(y_{s_{3}}-y_{s_{1}}\right)}{2 v_{s}{ }^{2} \tau_{13}} \text {. } \\
& k_{6}=\frac{\left(z_{s_{2}}-z_{s_{1}}\right)}{2 v_{s}{ }^{2} \tau_{12}}-\frac{\left(z_{s_{3}}-z_{s_{1}}\right)}{2 v_{s}{ }^{2} \tau_{13}} \text {. } \\
& k_{7}=\frac{k_{1}}{2 v_{s}{ }^{2} \tau_{12}}-\frac{k_{2}}{2 v_{s}{ }^{2} \tau_{13}} \text {. } \\
& 2 x k_{8}+2 y k_{9}+2 z k_{10}=k_{11} \text {. } \\
& k_{8}=\frac{\left(x_{s_{2}}-x_{s_{1}}\right)}{2 v_{s}^{2} \tau_{12}}-\frac{\left(x_{s_{4}}-x_{s_{1}}\right)}{2 v_{s}^{2} \tau_{14}} \text {. } \\
& k_{9}=\frac{\left(y_{s_{2}}-y_{s_{1}}\right)}{2 v_{s}{ }^{2} \tau_{12}}-\frac{\left(y_{s_{4}}-y_{s_{1}}\right)}{2 v_{s}{ }^{2} \tau_{14}} \text {. } \\
& k_{10}=\frac{\left(z_{s_{2}}-z_{s_{1}}\right)}{2 v_{s}{ }^{2} \tau_{12}}-\frac{\left(z_{s_{4}}-z_{s_{1}}\right)}{2 v_{s}{ }^{2} \tau_{14}} \text {. } \\
& k_{11}=\frac{k_{1}}{2 v_{s}{ }^{2} \tau_{12}}-\frac{k_{3}}{2 v_{s}{ }^{2} \tau_{14}} \text {. }
\end{aligned}
$$

These two planes (8) and (9) intersect in a line through the source. By substitution and elimination, the equations of line in a three dimensional space is obtained and given in (10).

$$
\begin{aligned}
& z=\frac{x+k_{12}}{k_{13}}=\frac{k_{14}-y}{k_{15}}=A . \text { (assuming) } \\
& k_{12}=\frac{k_{7} k_{9}-k_{5} k_{11}}{2\left(k_{5} k_{8}-k_{4} k_{9}\right)} .
\end{aligned}
$$




$$
\begin{aligned}
& k_{13}=\frac{k_{6} k_{9}-k_{5} k_{10}}{\left(k_{5} k_{8}-k_{4} k_{9}\right)} . \\
& k_{14}=\frac{k_{7} k_{8}-k_{4} k_{11}}{2\left(k_{5} k_{8}-k_{4} k_{9}\right)} . \\
& k_{15}=\frac{k_{6} k_{8}-k_{4} k_{10}}{\left(k_{5} k_{8}-k_{4} k_{9}\right)} .
\end{aligned}
$$

$A$ is variable and real. Coordinates of any point on the line can be obtained from (10) and are given in (11).

$$
z=A ; x=k_{13} A-k_{12} ; y=k_{14}-k_{15} A .
$$

By putting (11) in (5), the value of $T_{l}$ is obtained in terms of $A$ and constants and the simplified form is given in (12)

$$
\begin{aligned}
& T_{1}= k_{16}-A k_{17} . \\
& k_{16}=\frac{k_{1}+2 k_{12}\left(x_{s_{2}}-x_{s_{1}}\right)-2 k_{14}\left(y_{s_{2}}-y_{s_{1}}\right)}{2 v_{s}^{2} \tau_{12}} . \\
& k_{17}=\frac{k_{13}\left(x_{s_{2}}-x_{s_{1}}\right)-k_{15}\left(y_{s_{2}}-y_{s_{1}}\right)+\left(z_{s_{2}}-z_{s_{1}}\right)}{v_{s}{ }^{2} \tau_{12}} .
\end{aligned}
$$

Now, it is understood, that the source is located on the spheres as well as on the line. So intersecting point between line and the sphere gives the source location. Line intersects the spheres in two points. Out of these two points, solution is to be found.

$$
A^{2} k_{18}+A k_{19}+k_{20}=0 . \mathrm{q}
$$

By substituting $x, y, z$ form (11) and $T_{l}$ from (12) in (1), a quadratic equation in $A$ as in (13) is obtained.

$$
\begin{aligned}
& k_{18}=k_{13}{ }^{2}+k_{15}{ }^{2}+1-v_{s}{ }^{2} k_{17}{ }^{2} . \\
& k_{19}=2 v_{s}{ }^{2} k_{16} k_{17}-2 k_{13}\left(k_{12}+x_{s_{1}}\right)- \\
& -2 k_{15}\left(k_{14}-y_{1}\right)-2 z_{s_{1}} . \\
& k_{20}=\left(k_{12}+x_{1}\right)^{2}+\left(k_{14}-y_{1}\right)^{2}+ \\
& +z_{12}-v_{s}{ }^{2} k_{16}{ }^{2} .
\end{aligned}
$$

Solution of this gives two values for $A$. Subsequently, by substituting $A$, in (11) and (12), two sets of $\left[x, y, z\right.$ and $\left.T_{l}\right]$ are determined. Out of these two sets, one is accepted solution and other is rejected from a practical standpoint of view. It may be due to either $T_{l}$ being negative or $x, y, z$ being negative or outside the transformer tank.

\subsection{Importance of Sound Velocity for PD Localization Accuracy}

Sound velocity $\left(v_{s}\right)$ is one of the input parameters in noniterative algorithm (Fig. 4). Sound velocity is considered to be a constant. As it has been stated above, in reality this is far from truth thus making this approximation a potential huge source of error for algorithm's accuracy.

Other input variables, namely time differences of arrival $\tau_{l j}, j=2,3,4$, are dependant upon $v_{s}(14)$.

$$
\tau_{1 j}=v_{s}^{-1}\left(l_{j}-l_{1}\right) .
$$

In real measurements, all TDOA based methods' measurement accuracy is most influenced by accuracy of measurement of time differences of arrival [18]. It seems very interesting for further research to investigate this dependence of $\tau_{12}, \tau_{13}, \tau_{14}$ upon $v_{\mathrm{s}}$ and its infulence on accuracy of non-iterative algorithm.

There is no clear recommendation which value for sound velocity to use. The recommendation from [8] is to take the value of $1413 \mathrm{~m} / \mathrm{s}$ that corresponds to transformer oil temperature of $20^{\circ} \mathrm{C}$ (regardless of true value of transformer oil temperature). In [12] it is stated that variations in propagation velocity depending on different materials and conditions are important characteristic of the acoustic transmission path.

If we look at available PD detection systems manufacturers' instructions there is no clear recommendation either. Measurement personnel should rely on experience, knowledge of transformer construction, prior history of transformer operation etc. before determining which values for input parameters to use.

Nevertheless, some value for sound velocity has to be used in the algorithm.

All of this raised interest of the authors in understanding sound velocity's influence on PD localization accuracy.

\subsection{Sound velocity dependence on transformer oil temperature}

Sound velocity in transformer oil is largely dependent on transformer oil temperature. To a lesser extent, the velocity depends on acoustic signal frequency, as well as on transformer oil content of gas and water. If a high level of precision is to be achieved in determining sound velocity, it is necessary to take all the above parameters into consideration. However, for many practical purposes, including the research which is the subject of this article, the approximation taking into account only transformer oil temperature is sufficient [12]. Typical correlation between sound velocity and transformer oil temperature is taken from [31] and shown in Fig. 3.

This figure shows that temperature change within the range of $-30-130{ }^{\circ} \mathrm{C}$, causes sound velocity change in a wide range, from a maximum of approximately $1600 \mathrm{~m} / \mathrm{s}$ at lower values of transformer oil temperature to a minimum of approximately $1100 \mathrm{~m} / \mathrm{s}$ at its higher values.

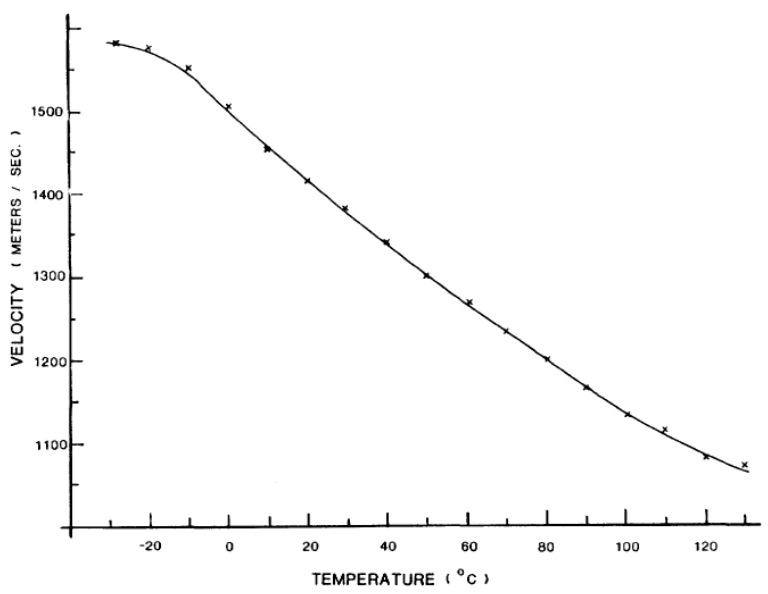

Figure 3. Graph presenting the change of sound velocity in correlation with transformer oil temperature. 


\subsection{Elementary sensitivites}

Since absolute errors in detecting the location of partial discharge $(\Delta x, \Delta y, \Delta z)$ are functions of several variables, this is described in a generalized form by equations:

$$
\begin{aligned}
\Delta g & =f\left(x, y, z, x_{s_{i}}, y_{s_{i}}, z_{s_{i}}, v_{s}, \tau_{12}, \tau_{13}, \tau_{14}\right) . \\
\Delta g & \equiv \Delta x \equiv \Delta y \equiv \Delta z .
\end{aligned}
$$

Partial derivatives to certain relevant values are determined by finding the total differential of (15):

$$
\begin{aligned}
& d(\Delta g)=\frac{\partial f}{\partial x} d x+\ldots+\frac{\partial f}{\partial x_{s_{1}}} d x_{s_{1}}+\ldots+\frac{\partial f}{\partial v_{s}} d v_{s}+\ldots \\
& \ldots+\frac{\partial f}{\partial \tau_{12}} d \tau_{12}+\ldots+\frac{\partial f}{\partial \tau_{14}} d \tau_{14} .
\end{aligned}
$$

In (17), partial derivatives represent elementary sensitivities. For example, $\partial f / \partial v_{s}$ represents elementary sensitivity to the change of sound velocity and is calculated at some fixed point of the input space. Finding this derivative consists of holding constant all variables other than the one with respect to the partial derivative is being found.

Taking into account the correlation between the acoustic propagation velocity and the transformer oil temperature and applying the chain rule, (17) becomes:

$$
\begin{aligned}
& d(\Delta g)=\frac{\partial f}{\partial x} d x+\ldots+\frac{\partial f}{\partial x_{s_{1}}} d x_{s_{1}}+\ldots+\frac{\partial f}{\partial T} d T+\ldots \\
& \ldots+\frac{\partial f}{\partial \tau_{12}} d \tau_{12}+\ldots+\frac{\partial f}{\partial \tau_{14}} d \tau_{14} .
\end{aligned}
$$

In this equation, $\partial f / \partial T$ stands for elementary sensitivity to the change of transformer oil temperature. Turning from differential to finite changes $(d \rightarrow \Delta)$, (18) becomes:

$$
\begin{aligned}
& \Delta(\Delta g) \approx \frac{\partial f}{\partial x} \Delta x+\ldots+\frac{\partial f}{\partial x_{s_{1}}} \Delta x_{s_{1}}+\ldots+\frac{\partial f}{\partial T} \Delta T+\ldots \\
& \ldots+\frac{\partial f}{\partial \tau_{12}} \Delta \tau_{12}+\ldots+\frac{\partial f}{\partial \tau_{14}} d \tau_{14} .
\end{aligned}
$$

Let us take that transformer oil temperature has the value of $T a$. Let us take that, instead of the correct value, we use a different value of $T b$ as the input value for transformer oil temperature. Let us allow that this change in temperature value has produced a change of the calculated absolute error from the value of $\Delta g_{T a}$ to the value of $\Delta g_{T b}$, that is:

$$
\begin{aligned}
& \Delta(\Delta g) \equiv \Delta(\Delta x) \equiv \Delta(\Delta y) \equiv \Delta(\Delta z) . \\
& \Delta(\Delta g)=\Delta g_{T b}-\Delta g_{T a} . \\
& \Delta T=|T b-T a|, \Delta x=\Delta x_{s_{1}}=\Delta \tau_{12}=\ldots=0 .
\end{aligned}
$$

Elementary sensitivity of the algorithm for detecting the location of partial discharge by the non-iterative all acoustic method with respect to transformer oil temperature change can be expressed as:

$$
\frac{\partial f}{\partial T} \approx \frac{\Delta(\Delta g)}{\Delta T}
$$

In simulations that are presented in chapter 4, nominal values for input parameters produce correct result. This means that absolute errors for this set of input values are equal to zero. In real measurements this, of course, is not the case. If for example $T a$ is considered to be nominal value for transformer oil temperature, (21) becomes:

$$
\Delta(\Delta g)=\Delta g_{T b}-\Delta g_{T a}=\Delta g_{T b} .
$$

This means that change of absolute error is equal to absolute error for the value of transformer oil temperature $T b$.

\subsection{The algorithm}

In previous chapters we discussed in detail all necessary elements for the construction, implementation and utilization of the algorithm:

- selecting input parameter(s) that is considered to be most important (sound velocity),

- defining input and output information,

- defining a procedure to calculate PD location,

- defining a procedure to approximately determine sound velocity value from value of transformer oil temperature,

- defining a procedure to calculate elementary sensitivity with respect to transformer oil temperature change.

The algorithm is illustrated via block diagram depicted in Figure 5.

The first block in Fig. 5, describes all input and output information. All values defined here will remain unchanged until the end of algorithm. These values are considered to be nominal (correct) values. Our goal is to change value of velocity of sound, recalculate PD location and observe change of PD location with respect to its nominal value. This change is expressed via absolute errors. The number of different values for $v_{s}$ that we use to probe PD location is marked with $N$. This process is presented in Fig. 5 by loop of $N$ repetitions. The loop ends when current repetition number $n$ reaches $N$. This produces a set of paired values $\Delta v_{s n}, \Delta T_{n}, \Delta x_{p d n}, \Delta y_{p d n}$, $\Delta z_{p d n}, n=1 \ldots N$ (25). These values represent the final result of the algorithm.

$$
\left[\begin{array}{ccccc}
\Delta v_{s 1} & \Delta T_{1} & \Delta x_{p d 1} & \Delta y_{p d 1} & \Delta z_{p d 1} \\
\Delta v_{s 2} & \Delta T_{2} & \Delta x_{p d 2} & \Delta y_{p d 2} & \Delta z_{p d 2} \\
\vdots & & \vdots & & \vdots \\
\vdots & & \vdots & & \vdots \\
\Delta v_{s N} & \Delta T_{N} & \Delta x_{p d N} & \Delta y_{p d N} & \Delta z_{p d N}
\end{array}\right]
$$

Instead of looking at each absolute error individually, we can find the maximum change of absolute error for each row:

$$
\left[\begin{array}{ccc}
\Delta v_{s 1} & \Delta T_{1} & \max (\Delta(\Delta g))_{1} \\
\Delta v_{S 2} & \Delta T_{2} & \max (\Delta(\Delta g))_{2} \\
\vdots & \vdots & \vdots \\
\Delta v_{s N} & \Delta T_{N} & \max (\Delta(\Delta g))_{N}
\end{array}\right] .
$$

Where, according to (24): 
$\max (\Delta(\Delta g))_{n}=\max \left(\Delta x_{p d n}, \Delta y_{p d n}, \Delta z_{p d n}\right)$.

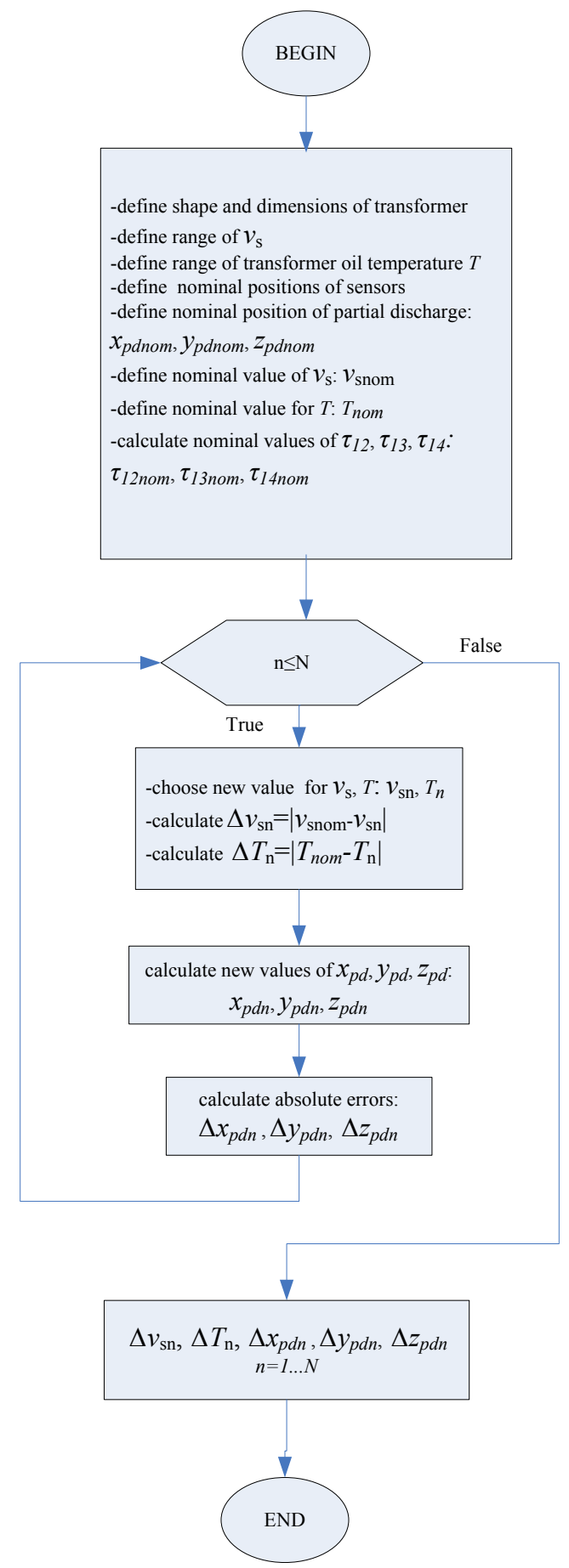

Figure 5. Algorithm for calculating influence of power transformer oil temperature change on the accuracy of allacoustic non-iterative PD localization.

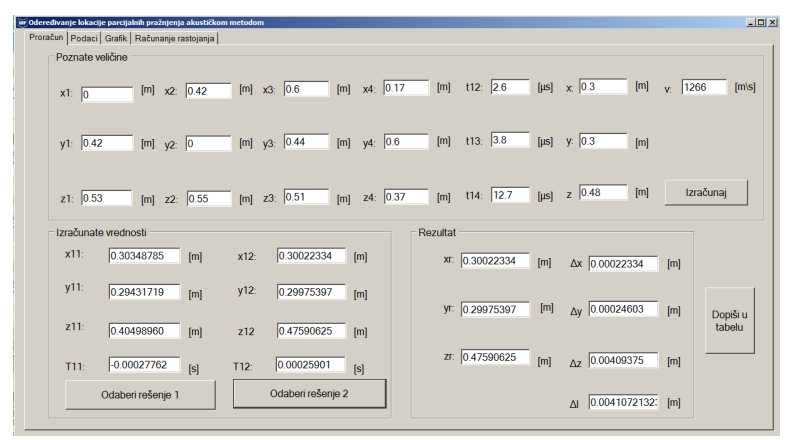

Figure 4. Software tool that implements the algorithm.
In order to effectively take advantage of this algorithm the authors implemented it in Visual C\# programming language (Fig. 4). This software tool is used to carry on several simulations which are presented in next chapter.

\section{SIMULATIONS}

For simulation, a cube shaped transformer with side length of $60 \mathrm{~cm}$ is considered. Each of 4 sensors is placed on a different side of the cube. Partial discharge is considered to be at $x_{p d}=30 \mathrm{~cm}, y_{p d}=30 \mathrm{~cm}, z_{p d}=48 \mathrm{~cm}$. This position is chosen as a potential position of high voltage winding in the considered cube shaped trans-former. Nominal value for oil temperature is $20^{\circ} \mathrm{C}$. Probing is done for 4 different oil temperatures (sound velocities) shown in Table 1.

Table 1. Approximate values for sound velocity for respectful temperatures of transformer oil.

\begin{tabular}{|l|c|c|c|c|c|}
\hline Oil temperature $\left[{ }^{\circ} \mathrm{C}\right]$ & 20 & 30 & 40 & 50 & 60 \\
\hline Sound velocity $[\mathrm{m} / \mathrm{s}]$ & 1414 & 1374 & 1337 & 1301 & 1266 \\
\hline
\end{tabular}

Six different sensors' positions (SP) are considered (Table 2). Placing sensors close to transformer's edges is avoided by placing every sensor more than $3 \mathrm{~cm}$ from every edge.

Table 2. Sensor coordinates for respectful sensors' position (SP).

\begin{tabular}{|c|c|c|c|c|c|c|c|c|c|c|c|c|}
\hline \multirow{2}{*}{ SP } & \multicolumn{10}{|c|}{ Sensor coordinates $[\mathrm{cm}]$} \\
\cline { 2 - 15 } & $x_{S 1}$ & $y_{S 1}$ & $z_{S 1}$ & $x_{S 2}$ & $y_{S 2}$ & $z_{S 2}$ & $x_{S 3}$ & $y_{S 3}$ & $z_{S 3}$ & $x_{S 4}$ & $y_{S 4}$ & $z_{S 4}$ \\
\hline 1 & 60 & 39 & 36 & 22 & 60 & 24 & 18 & 0 & 23 & 0 & 56 & 16 \\
\hline 2 & 50 & 60 & 30 & 0 & 36 & 20 & 60 & 11 & 19 & 15 & 0 & 10 \\
\hline 3 & 60 & 31 & 19 & 47 & 60 & 19 & 38 & 0 & 13 & 0 & 52 & 20 \\
\hline 4 & 0 & 29 & 43 & 13 & 60 & 34 & 60 & 36 & 19 & 46 & 0 & 20 \\
\hline 5 & 54 & 60 & 31 & 0 & 7 & 26 & 35 & 0 & 6 & 60 & 28 & 5 \\
\hline 6 & 0 & 42 & 53 & 42 & 0 & 55 & 60 & 44 & 51 & 17 & 60 & 37 \\
\hline
\end{tabular}

Results of the simulations are presented in Table 3, and depicted in Figure 5.

Table 3. Maximum change of maximum absolute error with respect to transformer oil temperature for corresponding SP from Table 2.

\begin{tabular}{|c|c|c|c|c|c|}
\hline \multirow{2}{*}{$\mathrm{SP} \backslash \max (\Delta(\Delta g))[\mathrm{cm}]$} & \multicolumn{5}{|c|}{ Oil temperature $\left[{ }^{\circ} \mathrm{C}\right]$} \\
\cline { 2 - 7 } & 20 & 30 & 40 & 50 & 60 \\
\hline 1 & - & - & - & - & - \\
\hline 2 & - & - & - & - & - \\
\hline 3 & 0 & 4 & 7 & 9 & 11 \\
\hline 4 & 0 & 1 & 3 & 4 & 5 \\
\hline 5 & 0 & 0 & 1 & 1 & 2 \\
\hline 6 & 0 & 0 & 0 & 0 & 0 \\
\hline
\end{tabular}

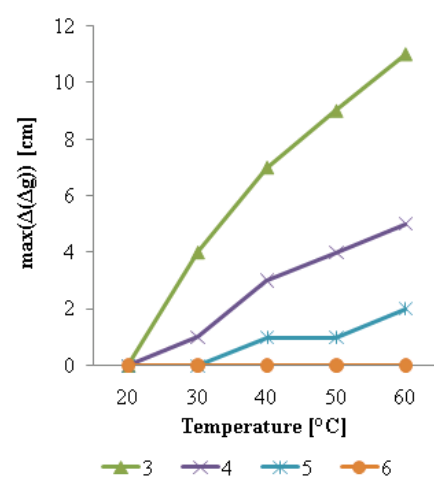

Figure 5. Graph presenting change of maximum absolute error with respect to transformer oil temperature for corresponding SP from Table 2. 
As seen in Fig. 5 different sensors' positions, for same position of partial discharge, produce significant disparity in maximum absolute error over temperature of oil. This disparity ranged from 0 at position 6 , to $11 \mathrm{~cm}$ at position 3 for temperature of $60^{\circ} \mathrm{C}$ (temperature change of $40^{\circ} \mathrm{C}$ ).

From the perspective of oil temperature change influence on PD detection accuracy, position 6 may be considered as far more suitable than other positions (for considered location of partial discharge).

On the other hand, sensors' positions 1 and 2 did not give valid solutions for location of partial discharge. In these cases non-iterative algorithm gave both positive roots (two possible solutions) or result that is out of bounds for considered transformer's dimensions. From the perspective of PD localization, these two positions may be considered as non applicable for sensor placement.

Illustrations of PD and sensors' placement from Table 2 are presented in Fig. 6-11.

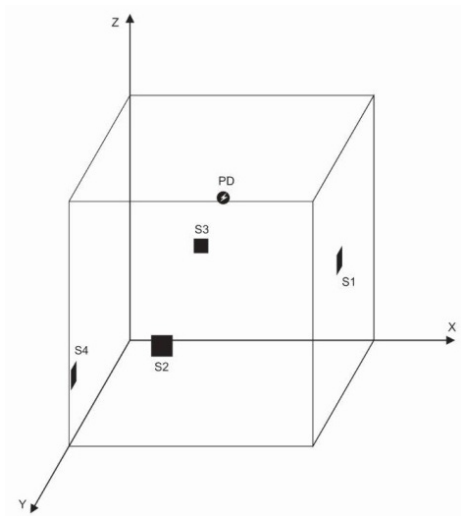

Figure 6. PD and sensor placements for SP 1 from Table 2

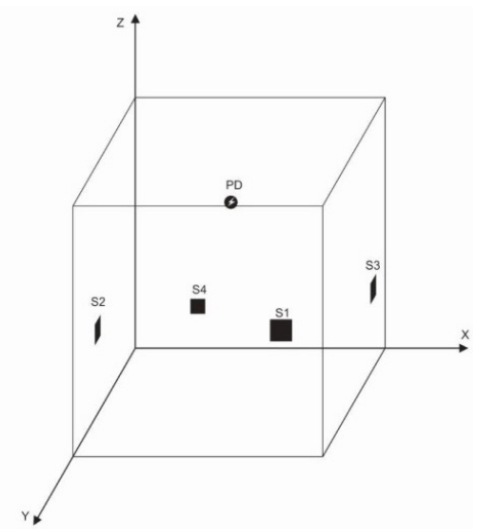

Figure 7. PD and sensor placements for SP 2 from Table 2

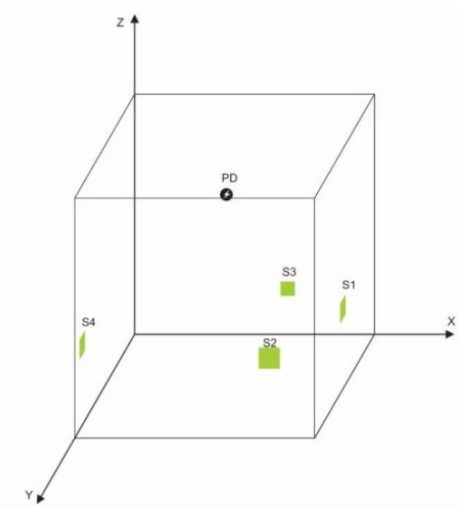

Figure 8. PD and sensor placements for SP 3 from Table 2

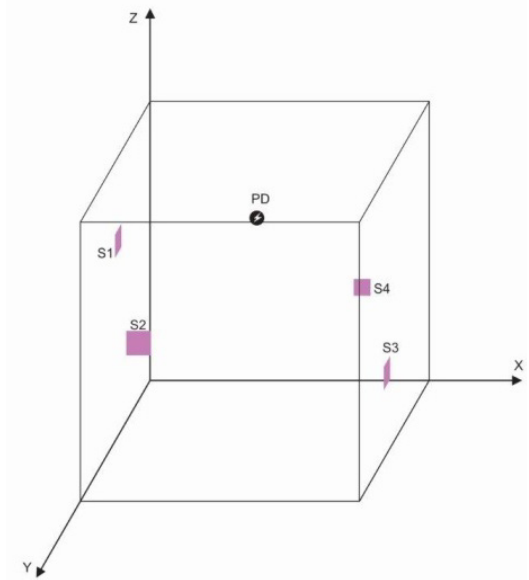

Figure 9. PD and sensor placements for SP 4 from Table 2

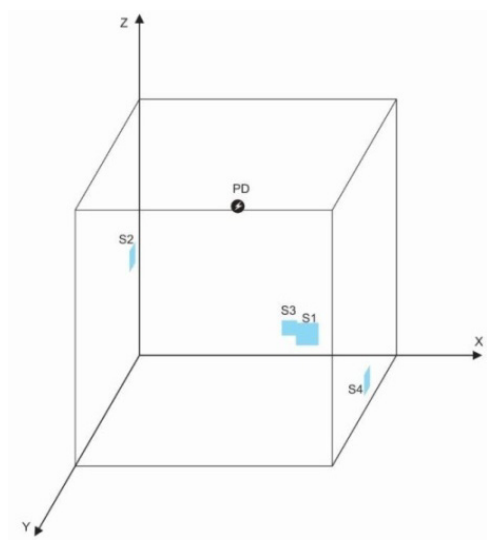

Figure 10. PD and sensor placements for SP 5 from Table 2

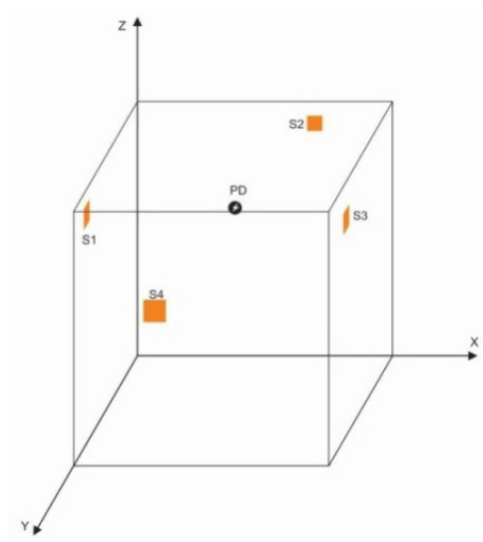

Figure 11. PD and sensor placements for SP 5 from Table 2

Maximum elementary sensitivity with respect to transformer oil temperature change is depicted in Fig. 12. As seen in Fig. 12 different sensors' positions, for same position of partial discharge, produce significant disparity in maximum elementary sensitivity over oil temperature change. This disparity ranged from 0 at position 6 , to $\left.0.4 \mathrm{~cm}\right|^{\circ} \mathrm{C}$ at position 3 for temperature of $30^{\circ} \mathrm{C}$ (temperature change of $10^{\circ} \mathrm{C}$ ).

Even though presented algorithm and simulations are vastly limited to draw any definite conclusion they point out to possible interaction between input variables that can be exploited in effort to improve PD localization accuracy by non-iterative all-acoustic method. This interaction is also, in a way, strongly hinted in [18] where two different RF antenna formations produced different accuracy levels in PD detection. 


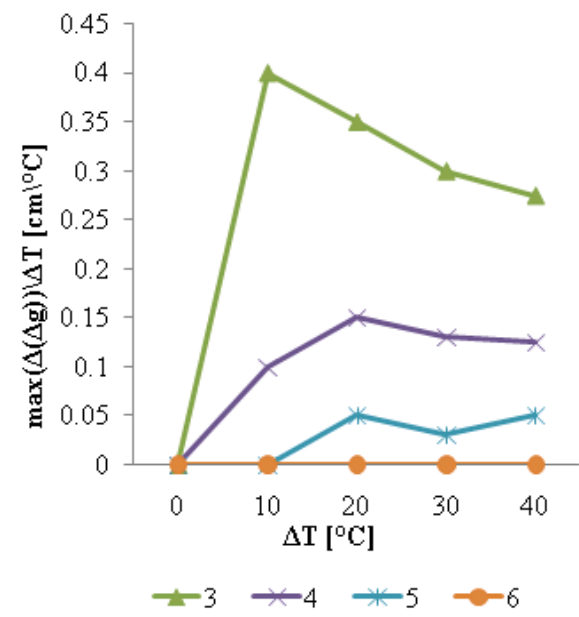

Figure 12. Graph presenting change of maximum elementary sensitivity with respect to transformer oil temperature change for corresponding SP from Table 2.

Ultimate usefulness of presented finding only comes about by its joining with real observations in experimental or field conditions. In order to accomplish that, authors present proposal for further research and development in next chapter.

\section{FURTHER RESEARCH AND DEVELOPMENT}

Roadmap for further research and development is shown in Fig. 13.

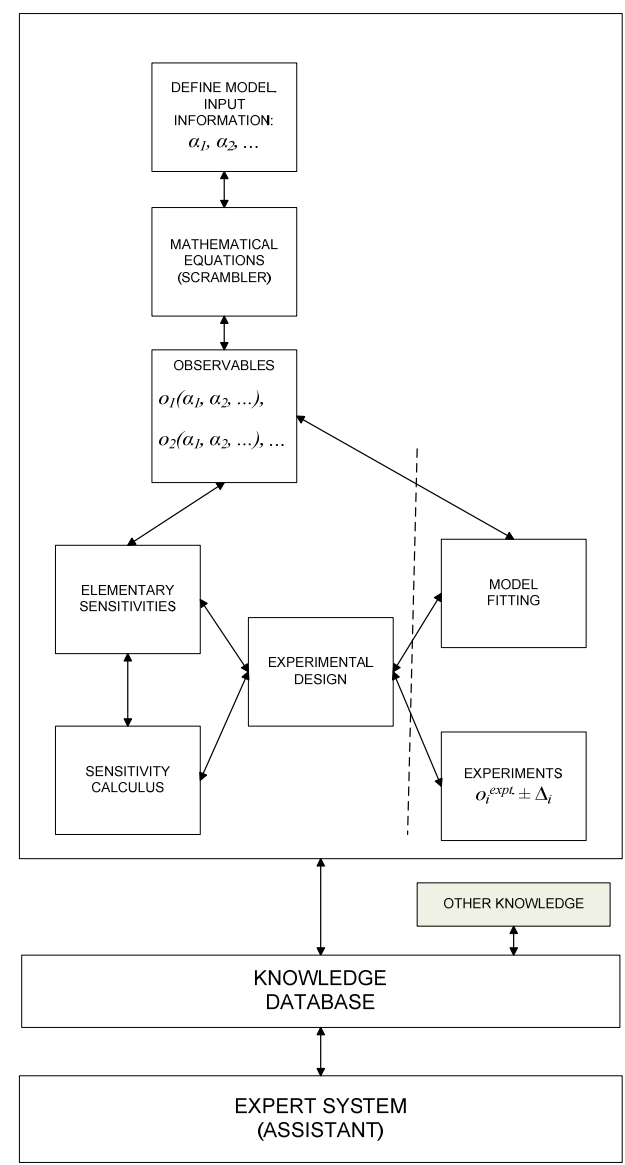

Figure 13. Roadmap for further research and development

Figure 13 illustrates the interrelationship of mathematical modeling, sensitivity analysis and actual experiments [35]. The vertical dashed line in this block inter- faces experiments with the modeling-sensitivity activities. Middle block represents all available knowledge obtained from the top block and other sources and is used by the bottom block which represents expert system [38, 39]. Expert system may be used by PD experts as assistant tool during PD localization.

For sensitivity calculus, deterministic methods, statistical methods or Monte Carlo methods may be used [36]. In Fig. 14 one proposal for the algorithm for global sensitivity calculus based on Monte Carlo method is shown. This algorithm uses algorithm presented in this paper as its foundation.

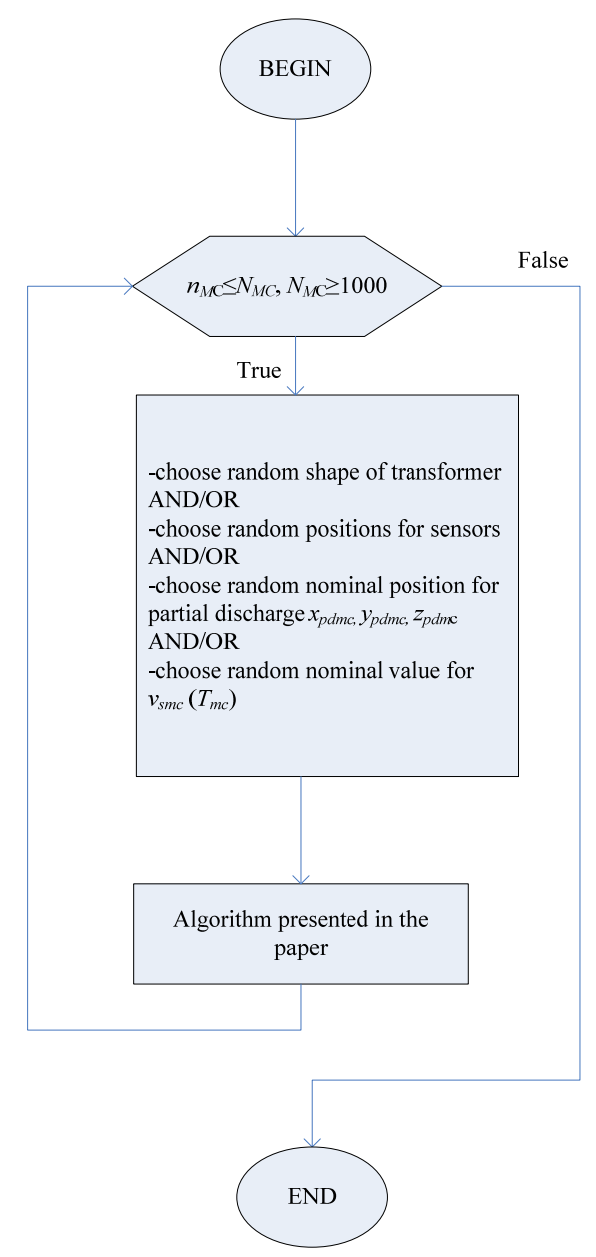

Figure 14. Proposal of algorithm for sensitivity calculus based on Monte Carlo method that uses algorithm described in the paper as its foundation.

What is interesting about this algorithm is that the number of different input parameters to be randomized is variable (marked with AND/OR in Fig. 14). This is mentioned because there is a relatively large number of input parameters which may aggravate observations. Non-iterative algorithm by itself has 16 input parameters. Sometimes it is easier to notice interactions between variables if we use this step by step approach.

The objective of local sensitivity analysis is to analyze the behavior of the system responses locally around a chosen point or trajectory in the combined phase space of parameters and state variables. On the other hand, the objective of global sensitivity analysis is to determine all of the system's critical points (bifurcations, turning points, response extremes) in the combined phase space formed by the parameters, state variables, and adjoint 
variables, and subsequently analyze these critical points by local sensitivity analysis [30].

If we put previous statement in perspective of our research: the goal is to determine point(s) from input space, where (17) has minimal value, by means of global sensitivity analysis. These points represent sensor positions where change of absolute error with respect to oil temperature change is minimal. For example, one candidate for such point is SP 6 from Table 2. Then, by the means of local sensitivity analysis analyze these points to gain further knowledge that is needed for experimental design and subsequent experiments.

\section{CONCLUSION}

This paper examines influence of oil temperature change (sound velocity change) on non-iterative all-acoustic PD localization accuracy. Basic algorithm made for that purpose is presented and implemented in Visual C\# programming language. Presented simulations pointed out to possible interaction between transformer oil temperature and placement of acoustic sensors. This can be exploited to improve PD detection accuracy. In order to fully take advantage of observed interaction, further research is necessary.

\section{REFERENCES}

[1] Rusiński, E., Czmochowski, J., Moczko, P., Pietrusiak, D.: Challenges and Strategies of Longlife Operation and Maintenance of Technical Objects, FME Transactions, Vol. 44, No 3, 2016, pp. 219-228, doi:10.5937/fmet1603219R

[2] Sousa, S., Nunes, E., Lopes, I.: Measuring and Managing Operational Risk in Industrial Processes, FME Transactions, Vol. 43, No 4, 2015, pp. 295302, doi:10.5937/fmet1504295S

[3] Kovačević, D., Škundrić, S. Lukić, J.: Monitoring and diagnostics of power transformer insulation, Thermal Science, 10 (2006), 4, pp. 43-54, DOI:10.2298/TSCI0604043K

[4] Strachan, S.M., Rudd S., McArthur S.D.J., Judd M.D.: Knowledge Based Diagnosis of Partial Discharges in Power Transformers, IEEE Transactions on Dielectrics and Electrical Insulation, Vol. 15, No. 1; pp. 259-268, February 2008.

[5] Osmokrović, P., Kartalović, N.: Applicabillity of Simple Expressions for Electrical Breakdown Probability Increase in Vacuum and Gas, IEEE Transactions on Power Szstems, 1997, Vol. 12, No. 4, pp. 1455-1460

[6] Hancox, R., Tropper, H.: The breakdown strength of transformer oil under impulse voltage, Proc. IEE (1957), pp250-262

[7] IEC 60270: 2000, High-voltage test techniquesPartial discharge measurements, https://webstore. iec.ch/publication/1247\#additionalinfo

[8] IEEE Std C57.127 - IEEE Guide for the Detection and Location of Acoustic Emissions From Partial Discharges in Oil-Immersed Power Transformers and Reactors, http://ieeexplore.ieee.org/servlet /opac?punumber $=4293263$
[9] Kundu, P., Kishore, N.K., Sinha, A.K.: Classification of Acoustic Emission Based Partial Discharge in Oil Pressboard Insulation System Using Wavelet Analysis, International Journal of Electrical and Electronics Engineering, Vol. 1, No. 4, pp. 208-215, 2008.

[10]Kumar, A.S., Gupta, R.P., Venkatasami, A., K.: Design Parameter Based Method of Partial Discharge Detection and Location in Power Transformers, Serbian Journal of Electrical Engineering Vol. 6, No. 2, November 2009, pp. 253-265.

[11] Posada-Roman, J. et al.: Fiber Optic Sensor for Acoustic Detection of Partial Discharges in OilPaper Insulated Electrical Systems, Sensors 2012, 12(4), pp. 4793-4802.

[12] IEC 62478/Ed1, 2016: High Voltage Test Techniques- Measurement of Partial Discharges by Electromagnetic and Acoustic Methods

[13] Gray, I.A.R.: A Guide to Transformer Oil Analysis.

[14]Lemke, E.: Guide for Partial Discharge measurements in compliance to IEC 60270, CIGRE, WG D1.33, December 2008.

[15] Ji T. Y, Tang W. H, Wu Q. H.: Partial discharge location using a hybrid transformer winding model with morphology-based noise removal, Electric Power Systems Research 2013; 101: 9-16.

[16] Sarathi, R., Reid, A. J., Judd, M. D.: Partial discharge study in transformer oil due to particle movement under DC voltage using the UHF technique, Electric Power Systems Research 2008; 78: 1819-1825.

[17]Herman, H. H., Phung, B. T., Blackburn, T. R.: Recognition of single and multiple partial discharge sources in transformers based on ultrahigh frequency signals, IET Generation, Transmission \& Distribution 2013; 8: 160-169.

[18] Mountassir, O. et al.: Quantification of the performance of iterative and non iterative computational methods of locating partial discharges using $R F$ measurement techniques, Electric Power Systems Research 2017; 143: 110-120.

[19] Ramirez-Nino, J., Pascacio, A.: "Acoustic measuring of partial discharge in power transformers," Measurement Science and Technology, Vol. 20, No. 11 (2009) 115108 (9pp)

[20] Phung, B.T., Blackburn, T.R., Liu, Z.Z.: "Acoustic Measurements of Partial Discharge Signals," Journal of Electrical \& Electronics Engineering, Australia, Vol. 21(1), pp. 41 - 48, 2001

[21] Santos Filho, O. G., Zaghetto, S. L., Pereira, G. O.: "Case Studies of Electric Power Equipment Diagnostics Using Acoustic Emission," 17th World Conference on Nondestructive Testing, 25-28 Oct 2008, Shanghai, China

[22] Kishore, N.K. et al:: A non-iterative partial discharge source location method for transformers employing acoustic emission techniques, Applied Acoustics, 70 (2009), 11-12, pp. 1378-1383 
[23] Sikorski, W.,Walczak, K.: Power Transformer Diagnostics Based on Acoustic Emission Method, in: Acoustic Emission - Research and Applications (Ed. Dr. Wojciech Sikorski), InTech, 2013, DOI: $10.5772 / 55211$

[24] Markalous, S., Tenbohlen S., Feser K.: "Detection and location of partial discharges in power transformers using acoustic and electromagnetic signals," Dielectrics and Electrical Insulation, IEEE Transactions on, vol.15, no.6, pp.1576,1583, December 2008, doi: 10.1109/TDEI.2008.4712660

[25] MacAlpine, M., Zhiqiang, Z., Demokan, M.: Development of a fibre-optic sensor for partial discharges in oil-filled power transformers. Electric Power Systems Research 2002; 63: 27-36.

[26]CIGRE, Technical Brosure No. 444, Working Group d1.22: Guidelines for Unconventional Partial Discharge Measurements, 2010, ISBN 9782-85873-132-9.

[27]CIGRE, Technical Brosure No. 502, Working Group D1.22: High-Voltage On-Site Testing with Partial Discharge Measurement, 2012, ISBN 978-285873-194-7.

[28] Coenen, S., Tenbohlen, S.: Location of PD Sources in Power Transformers by UHF and Acoustic Measurements, IEEE Transactions on Dielectrics and Electrical Insulation ( Volume: 19, Issue: 6, December 2012 ), pp. 1934-1940

[29] Salom, I.: et al., Laboratory experimental system for examination of acoustic emission generated by partial discharges, Telfor Journal, 2013, vol. 5, Issue: 2, pp. 134-139

[30]Loganathan, T., Murty, K., Chandraskan, K., Damage characterization of GFRP composite on exposure to cyclic loading by acoustic emission, FME Transactions, 2016, Vol 44, iss 2, pp 139-145.

[31] Howells, E., Norton, E.T.: Parameters affecting the velocity of sound in transformer oil, IEEE Transaction on Power Apparatus and Systems, PAS-103 (1984), 5, pp. 1111-1115, DOI: 10.1109/TPAS.1984.318719

[32] Radakovic, Z., Feser, K.: A New Method for the Calculation of the Hot-Spot Temperature in Power Transformers With ONAN Cooling, IEEE Transactions on Power Delivery, Vol. 18, No. 4, October 2003

[33] Radakovic, Z., Sorgic, M.: Basics of Detailed Thermal-Hydraulic Model for Thermal Design of Oil Power Transformers, IEEE Transactions on Power Delivery, Vol. 25, No. 2, April 2010

[34] Bancroft, S.: An algebraic solution of the GPS equations, IEEE Trans. Aerosp. and Elec. Systems, 21(7), 56-59

[35] Rabitz, H.: Sensitivity Analysis Theory with Applications to Molecular Dynamics and Kinetics,
Computers \& Chemistry, Vol. 5, No. 4, pp. 167180,1981

[36] Cacuci, D.G.: Sensitivity and uncertainty analysis theory, 2003 by Chapman \& Hall/CRC

[37] Dae-Won Park et al.: "Positioning of Partial Discharge Origin by Acoustic Signal Detection in Insulation Oil", Journal of International Council of Electrical Engineering, The Korean Institute of Electrical Engineers, vol. 2, no. 1. 2012. Korea Maritime University, Korea

[38] Russel, S., Norvig, P.: - Artificial Intelligence - A Modern Approach

[39] Russel, S., Norvig, P.: - Artificial Intelligence - A Modern Approach 2.

\section{АЛГОРИТАМ ЗА ПРОРАЧУН УТИЦАЈА ПРОМЕНЕ ТЕМПЕРАТУРЕ ТРАНСФОР- МАТОРСКОГ УЉА НА ПРЕЦИЗНОСТ ЛОКАЛИЗАЦИЈЕ ПАРЦИЈАЛНОГ ПРАЖ- ЊЕЊА ЧИСТО АКУСТИЧКОМ НЕИТЕРА- ТИВНОМ МЕТОДОМ У ЕНЕРГЕТСКОМ ТРАНСФОРМАТОРУ}

\section{В. Полужански, У. Ковачевић, Б. Николић}

Овај рад разматра чисто акустичку методу за локализацију парцијалног пражњења у енергетском трансформатору. Ова метода се заснива на математичком моделу који користи мултилатерацију, принцип временске разлике кашњења сигнала и неитеративни математички алгоритам. У овом моделу претпоставља се да акустички сигнал пролази једино кроз трансформаторско уље и да је брзина акустичког сигнала константна. Брзина акустичког сигнала у великој мери зависи од температуре трансформаторског уља што значи да се и температура трансформаторског уља сматра константном. У реалним условима, са аспекта физике, термодинамике флуида, конструкције трансформатора итд., ова претпоставка је најблаже речено велика. Управо зато се у овом раду истражује утицај промене температуре трансформаторског уља (промене брзине акустичког сигнала) на прецизност разматране методе. За ту намену, дизајниран је алгоритам и имплементиран у програмском језику Visual С\#. На основу спроведених симулација стечена су нова сазнања о интеракцији између температуре трансформаторског уља и положаја акустичких сензора. Ова интеракција довела је до значајне разлике у прецизности неитеративног математичког алгоритма за различите положаје акустичких сензора при промени температуре трансформаторског уља. Како би се уочена интеракција максимално искористила за унапређење прецизности разматране методе, предложени су одређени кораци за даље истраживање и развој. 